\title{
Aneuclis aenigmatica, a new remarkable species from Southwestern Mexico (Hymenoptera: Ichneumonidae: Tersilochinae)
}

\author{
Aneuclis aenigmatica - новый примечательный виА \\ из Юго-западной Мексики \\ (Hymenoptera: Ichneumonidae: Tersilochinae)
}

\author{
A.I. Khalaim ${ }^{1,2}$, E. Ruîz-Cancino ${ }^{1}$, J.M. Coronado-Blanco ${ }^{1}$ \\ А.И. Хацаим ${ }^{1,2}$, Э. Руис-Канцино ${ }^{1}$, Х.М. Коронадо-БАанко ${ }^{1}$
}

\footnotetext{
' Facultad de Ingeniería y Ciencias, Universidad Autónoma de Tamaulipas, Cd. Victoria, Mexico.

${ }^{2}$ Zoological Institute, Russian Academy of Sciences, Universitetskaya nab. 1, St. Petersburg 199034, Russia. E-mail: ptera@mail.ru

2 Зоологический институт РАН, Университетская наб. 1, Санкт-Петербург, Россия.
}

KEY WORDS: Jalisco, Nearctic region, North America, new species, taxonomy.

КЛЮЧЕВЫЕ СЛОВА: Халиско, Неарктика, Северная Америка, новый вид, систематика.

PALABRAS CLAVE: Jalisco, región Neártica, Norteamérica, nueva especie, taxonomía.

ABSTRACT. A new tersilochine species, Aneuclis aenigmatica Khalaim et Ruíz-Cancino, sp.n., is described from the State of Jalisco in Southwestern Mexico. In spite of the fact that the species is represented by a single poorly preserved male without antennae, it is immediately distinguished from all North American congeners by the head lacking occipital carina dorsally, infumate with brown wings and very short metacarpus.

RESUMEN. Se describe una nueva especie tersiloquina, Aneuclis aenigmatica Khalaim et Ruíz-Cancino, sp.n., del Estado de Jalisco en el suroeste de México. Aunque esta especie está representada por sólo un especimen macho pobremente preservado, inmediatamente se distingue de todos sus congéneres norteamericanos porque la carina occipital en la cabeza está ausente dorsalmente, alas ahumadas con color pardo y con el metacarpo muy corto.

РЕЗЮМЕ. Новый вид наездников-терзилохин, Aneuclis aenigmatica Khalaim et Ruíz-Cancino, sp.n. описан из штата Халиско в Юго-западной Мексике. Несмотря на то, что вид представлен одним самцом плохой сохранности и без антенн, он легко отличим от всех северо-американских сородичей по отсутствию затылочного валика сверху на голове, крыльям с коричневым затемнением и очень коротким метакарпом.

\section{Introduction}

Aneuclis Förster, 1869 is a moderately large genus of Tersilochinae (Hymenoptera: Ichneumonidae) with 33 described species occurring in the Holarctic, Afrotropical and Oriental regions [Yu et al., 2016; Khalaim, 2018]. One species, A. pumilus (Holmgren, 1860), is distributed almost worldwide, but probably it is originated from Europe [Gauld, 1984].

Horstmann [2012] revised four species of Aneuclis occurring in America north of Mexico, and one more species, A. pumilus, was recently transferred to this genus from Sathropterus Förster, 1869 [Khalaim, 2018]. Only one species, A. pumilus, was known from Mexico hitherto [Khalaim et al., 2015]. The aim of this study is to describe a second species of Aneuclis from Southwestern Mexico.

\section{Material and Methods}

The holotype of the new species is deposited in the Autonomous University of Tamaulipas, Cd. Victoria, Mexico (UAT). Colour photographs were taken at the Zoological Institute of the Russian Academy of Sciences with a Canon EOS 70D digital camera attached to an Olympus SZX10 stereomicroscope, and partially focused images were combined using Helicon Focus 6.7.1 Pro software.

How to cite this article: Khalaim A.I., Ruíz-Cancino E., Coronado-Blanco J.M. 2019. Aneuclis aenigmatica, a new remarkable species from Southwestern Mexico (Hymenoptera: Ichneumonidae: Tersilochinae) // Russian Entomol. J. Vol.28. No.1. P.66-68. doi: 10.15298/rusentj.28.1.10 


\section{Results}

Aneuclis aenigmatica Khalaim et Ruíz-Cancino, sp.n. Figs 1-4.

MATERIAL EXAMINED. Holotype: $\sigma^{\top}$, Mexico, [State of] Jalisco, W of Guadalajara, Zapopan, ca. Hotel Intercity [20 $41^{\prime} 48^{\prime \prime} \mathrm{N}$, $103^{\circ} 27^{\prime} 13^{\prime \prime} \mathrm{W}$ ], Yerbas [herbs], $1650 \mathrm{~m}, 22$ September 2011, coll. J.M. Coronado-Blanco \& E. Ruíz-Cancino (UAT).

DESCRIPTION. Male. Body length $3.25 \mathrm{~mm}$. Fore wing length $2.65 \mathrm{~mm}$.

Head roundly tapered behind eyes in dorsal view; gena almost 0.8 times as long as eye width (Fig. 1). Eyes with short sparse setae. Clypeus (Fig. 2) lenticular, 3.0 times as broad as long, more or less flat centrally, slightly convex laterally and in upper part, smooth and shining in lower 0.8 , scabrous in upper 0.2 , with distinct punctures in upper 0.3 , separated from face by distinct groove. Mandible very weakly tapered, with upper tooth slightly longer and slightly broader than the lower. Malar space as long as basal mandibular width. Maxillary palp with 4 palpomeres, labial palp with 3 palpomeres. Antennae missing. Face with very weak median convexity. Face distinctly granulate, dull, impunctate; granulation on median convexity is shallower. Frons almost smooth, with very small scattered punctures. Vertex polished, with rare and very fine punctures. Gena smooth, very shallowly granulate near occipital carina and in lower part, with very fine and sparse punctures. Occipital carina absent dorsally, present ventrally and laterally. Hypostomal carina absent.

Mesosoma distinctly granulate, dull, without distinct punctures; granulation in centre of lateral and median lobes of mesoscutum shallow. Notaulus distinctly impressed and with strong longitudinal wrinkle on anterolateral side of mesoscutum (Figs 3, 4). Scutellum weakly convex in lateral view, with lateral longitudinal carinae developed only at its extreme base. Epicnemial carina well developed, with upper end bent forwards and reaching front margin of mesopleuron at level of lower 0.3 of pronotum (Fig. 3). Foveate groove very broad, shallow, extending in anterior 0.8 of mesopleuron, weakly upcurved anteriorly, entirely covered by irregular wrinkles (Fig. 3). Propodeum with distinct basal keel which is about 0.4 times as long as apical area. Propodeal spiracle small, separated from pleural carina by almost 3.0 times diameter of spiracle. Transverse carina strong, with short adjacent wrinkles. Apical area narrowly rounded anteriorly, with fine irregular wrinkle; apical longitudinal carinae complete, reaching transverse carina anteriorly.
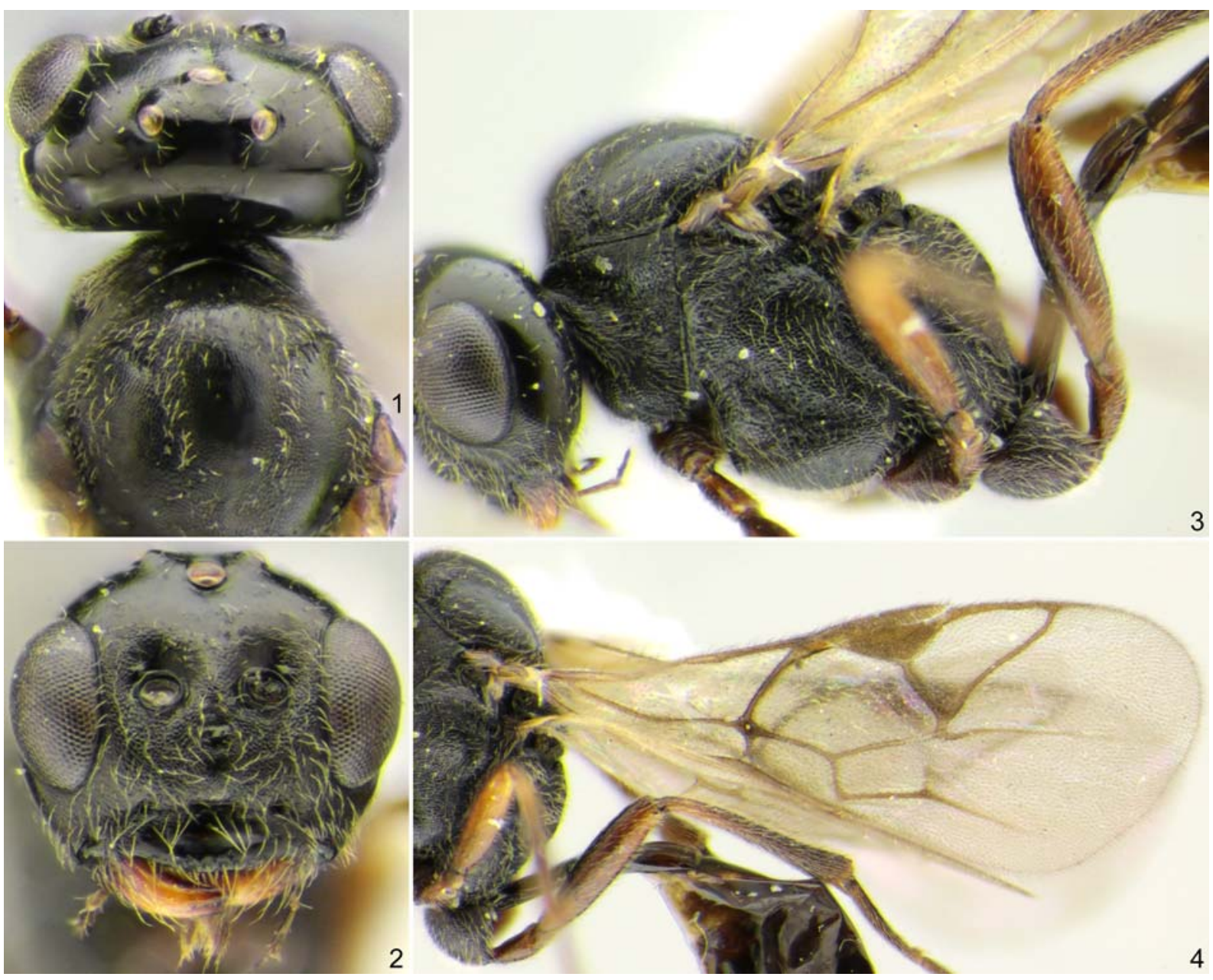

Figs 1-4. Aneuclis aenigmatica sp. n., male, holotype: 1 - head and mesoscutum, dorsal view; 2 - head, front view; 3 - head, mesosoma and base of metasoma, lateral view; 4 - wings.

Рис. 1-4. Aneuclis aenigmatica sp. n., самец, голотип: 1 - голова и мезоскутум, сверху; 2 - голова, спереди; 3 — голова, мезосома и основание метасомы, сбоку; 4 - крылья. 
Fore wing (Fig. 4) with second recurrent vein $(2 \mathrm{~m}-\mathrm{cu})$ postfurcal, absent in anterior half and vestigial in posterior half. Intercubitus (2rs-m) thick, longer than abscissa of cubitus between intercubitus and second recurrent vein (abscissa of $\mathrm{M}$ between $2 \mathrm{rs}-\mathrm{m}$ and $2 \mathrm{~m}-\mathrm{cu}$ ). First abscissa of radius $($ Rs $+2 r)$ thick, slightly arcuate, somewhat longer than width of pterostigma. First and second abscissae of radius (Rs $+2 r$ and Rs) meeting at right angle. Second abscissa of radius (Rs) somewhat sinuous. Metacarpus (R1) very short, slightly projecting beyond distal corner of radial cell (Fig. 4). Second abscissa of postnervulus completely absent, thus brachial cell is open posteriorly. Hind wing with nervellus (cu1\&cu-a) reclivous, slanted about $55^{\circ}$ from horizontal. Legs slender; hind femur $4.0 \times$ as long as broad. Tarsal claws long, not pectinate, weakly curved at apex.

First metasomal tergite 3.8 times as long as posteriorly broad, slightly depressed, dorsally smooth, petiole laterally and ventrally striate; spiracles situated on lateral swellings in apical 0.6 of tergite; glymma absent. Second tergite almost 1.9 times as long as anteriorly broad. Thyridial depression shallow, elongated. Metasoma behind first tergite strongly compressed.

Head (including clypeus) and mesosoma black; mouthparts brown to dark brown; mandible brownish yellow, darkened at base and with teeth dark red. Wings infumate with brown; tegula, pterostigma and veins brown. Fore and mid legs predominantly yellow-brown; coxae dark reddish brown; femora basally, tibiae apically and tarsi entirely darkened with brown. Hind leg with coxa brownish black; trochanters and femur dark brown (femur apically paler); tibia brownish basally to brownish black apically; and tarsus entirely blackish. Metasoma dark brown to brownish black.

Female. Unknown.

COMPARISON. The new species is immediately distinguished from other North American species of the genus by the occipital carina completely absent dorsally (Fig. 1), entirely black clypeus (Fig. 2) and fore wing with very short metacarpus (Fig. 4). The species is also characterized by the head polished dorsally (Fig. 1), notaulus with a strong wrinkle (Fig. 4), wings infumate with brown and with vein $2 \mathrm{~m}-\mathrm{cu}$ almost completely obliterated (Fig. 4). Unfortunately, $A$. aenigmatica sp.n. is represented by a single male lacking antennae, but its spectacular features will undoubtedly make possible recognition of its female.

ETYMOLOGY. The species is named from the Latin aenigmaticus (enigmatic).

DISTRIBUTION. Southwestern Mexico (Jalisco).

Acknowledgements. This work was supported by the PRODEP project "Taxonomical and biological studies of pests and natural enemies in Mexico". The work of the senior author was performed in the framework of the Russian State Research Project No. 01201351189 and supported by the Russian Foundation for Basic Research (project No. 19-0400027).

\section{References}

Gauld I.D. 1984. Subfamily Tersilochinae. In: An Introduction to the Ichneumonidae of Australia // Bulletin of the British Museum (Natural History) (Entomology). Vol.895. P.304-316.

Horstmann K. 2012. Revisions of Nearctic Tersilochinae III. Genera Aneuclis Förster and Diaparsis Förster (Hymenoptera, Ichneumonidae) // Spixiana. Bd.35. H.1. P.117-142.

Khalaim A.I. 2018. The genera Allophrys Förster and Aneuclis Förster (Hymenoptera: Ichneumonidae: Tersilochinae) of Vietnam // Zootaxa. Vol.4378. No.3. P.414-428. doi:10.11646/ zootaxa.4378.3.9.

Khalaim A.I., Ruíz-Cancino E., Coronado-Blanco J.M. 2015. First record of Sathropterus pumilus (Holmgren) (Hymenoptera: Ichneumonidae: Tersilochinae) from Mexico // Acta Zoológica Mexicana. Vol.31. No.1. P.138-139. doi:10.21829/azm.2015.311532.

Yu D.S.K., van Achterberg C., Horstmann K. 2016. Taxapad 2016, Ichneumonoidea 2015. Database on flash-drive. Nepean, Ontario, Canada. 